\title{
Tomasz Cituchowski
}

Akademia Muzyczna we Wroctawiu, Wroctaw

\section{Przekształcenia melodyczne w notacji rękopisu nr 44 Archiwum Krakowskiej Kapituty Katedralnej na przykładzie introitu Introduxit vos}

Tam, gdzie człowiek wysławia Boga, samo słowo nie wystarcza ${ }^{1}$. Od początku myśli zbawczej, jaką prowadzi Kościół, muzyka i śpiew są jego uroczystym językiem. Ich związek z liturgią był zawsze istotny i pozostanie taki do końca ${ }^{2}$. Nie sposób przecenić historycznego znaczenia słynnego powiedzenia św. Augustyna „Qui bene cantat bis orat” - po raz pierwszy tak jasno wyrażonego przeświadczenia o predylekcji liturgii i modlitwy chrześcijańskiej do muzycznych form wyrazu oraz przekonania o istotnym związku chwalby Bożej ze śpiewem³ ${ }^{3}$.

Przedmiotem niniejszego artykułu jest introit Introduxit vos przeznaczony na poniedziałek w oktawie wielkanocnej. Autor podjął się badań nad przekształceniami melodycznymi tego introitu zapisanego w notacji liniowej w krakowskim Graduale Jana Olbrachta. Zastosował w tym celu metodę historyczno-analityczno-porównawczą, ukazał genezę tekstu literackiego oraz szczegółowo zanalizował przebieg melodyczno-rytmiczny i związek melodyczno-słowny introitu. Zawarł również syntezę badań, wykazując najpierw podobieństwa do najstarszych źródeł, a następnie różnice i modyfikacje w przebiegu linii melodycznej introitu, wyprowadzając logikę zmian. Ujawnił także zjawisko zapisu częstych likwescencji, które w wyniku podjętych badań okazało się cechą charakterystyczną krakowskiej wersji Introduxit vos.

Autor ma nadzieję, że pozycja ta stanowić będzie skromny wkład w przywracanie utraconego piękna, które niesie ze sobą śpiew gregoriański, a także stanie się pomocą dla badaczy chcących zgłębić tajniki niepublikowanego rę-

1 J. Ratzinger, Nowa pieśń dla Pana. Wiara w Chrystusa a liturgia dzisiaj, tłum. J. Zychowicz, Kraków 1999, s. 175.

2 J. Pikulik, Śpiew i muzyka w historii liturgii, „Ateneum Kapłańskie” 437 (1980), s. 186.

3 M. Szczepankiewicz, Cantate Domino. Szkice o kulturze muzycznej kościota, Szczecin 2005, s. 19 . 
kopisu nr 44 Archiwum Krakowskiej Kapituły Katedralnej - Graduału Jana Olbrachta.

W myśl idei przyświecającej autorowi na początku poddano analizie zarówno tekst, jak i melodię graduału oraz ich wzajemne oddziaływanie, które zostało utrwalone w XVI-wiecznym zapisie krakowskim. Oryginalny tekst łaciński badanego introitu ma następujące brzmienie:

Introduxit vos Dominus in terram fluentem lac et mel, alleluia:

Et ut lex Domini semper sit in ore vestro, alleluia, alleluia.

Polskie tłumaczenie introitu brzmi:

Wprowadził was Pan do ziemi opływającej mlekiem i miodem, alleluja:

Aby też prawo Pańskie zawsze było na ustach waszych, alleluja, alleluja ${ }^{4}$.

Źródłem tekstu introitu, które jest zarazem bezpośrednim nawiązaniem do Biblii, są wersety piąty i dziewiąty z trzynastego rozdziału Księgi Wyjścia ${ }^{5}$ Brzmią one następująco:

5. Gdy zaś Pan wprowadzi cię do kraju Kananejczyka, Chetyty, Amoryty, Chiwwity, Jebusyty, jak poprzysiąg przodkom twoim dać im ziemię opływającą w mleko i miód, wtedy winieneś obchodzić to święto w tym samym miesiącu. (...) 9. Będzie to dla ciebie znakiem na ręce i przypomnieniem między oczami, aby prawo Pana było w ustach twoich, gdyż ręką potężną wywiódł cię Pan z Egiptu'.

We wszystkich wersjach porównywanych rękopisów (Graduał Olbrachta - Krk, manuskrypt Laon 239 - Lan, rękopis Eisiedeln 121 - Ein, rękopis Gaillac 776 - Glc) tekst introitu jest identyczny. Jedyna drobna różnica występuje w Krk w zapisie słowa terram - użyta jest skrócona forma terrā. Rozbiór gramatyczny tekstu przedstawia się następująco:

Introdúxit-czasownik, 3 os. 1. poj., str. czynna, czas przeszły, tryb wskazujący, trzecia koniugacja,

4 Mszat rzymski, Poznań 1963, s. 418-419.

5 W rozdziale tym zawarty jest początek opowieści o cudownym przejściu Izraela przez Morze Czerwone (Wj 13, 17-22, Wj 14, 1-31).

6 Pismo Święte Starego i Nowego Testamentu, Poznań-Warszawa 1980, s. 80. 
vos - zaimek osobowy, r. męski, biernik, l. mnoga,

Dóminus - rzeczownik, r. męski, l. poj., mianownik,

in-przyimek,

terram - rzeczownik, r. żeński, l. poj., biernik, pierwsza deklinacja,

fluéntem - imiesłów, str. czynna, czas teraźniejszy, trzecia koniugacja,

lac - rzeczownik, r. nijaki, l. mn., biernik, trzecia deklinacja,

et-spójnik,

mel-rzeczownik, r. nijaki, l. mn., biernik, trzecia deklinacja,

allelúia - rzeczownik, r. żeński, nieodmienny,

Et - spójnik podrzędny,

ut - spójnik łączny,

lex - rzeczownik, r. żeński, l. poj., mianownik, trzecia deklinacja,

Dómini - rzeczownik, r. męski, l. poj., mianownik, druga deklinacja, semper-przysłówek,

sit-czasownik, 3 os. l. poj., str. czynna, tryb przypuszczający, czas teraźniejszy, nieregularny,

in - przyimek,

ore - rzeczownik, r. nijaki, l. poj., narzędnik, trzecia deklinacja,

vestro - zaimek osobowy, r. nijaki, narzędnik, l. poj.,

allelúia, allelúia - rzeczownik, r. żeński, nieodmienny.

Zwróćmy teraz uwagę na przebieg melodyczno-rytmiczny badanego introitu. Nad sylabami przedakcentowanymi czasownika introdúxit zarówno kopista rękopisu krakowskiego, jak i kopiści wcześniejsi notują neumy jednodźwiękowe: Krk i Glc przekazują punctum na stopniu re, notacja manuskryptu z Laon uncinus, natomiast Ein dwa tractulusy. Interesujące jest pierwsze likwescencyjne punctum skryby krakowskiego. Sylabie akcentowanej badanego czasownika wszyscy notatorzy przyporządkowali neumę trójdźwiękową. Rękopis Krk przekazuje dźwięki re-fa-sol, podobnie robi to diastematyczny zapis akwitański, natomiast adiastematyczny zapis metzeński notuje scandicus, a sanktgalleński salicus. Czasownik introduxit zamyka w sylabie końcowe clivis: Krk notuje dźwięki sol-fa, podobnie jak kodeks akwitański, z kolei notacje adiastematyczne wskazują na poszerzenie przez epizemę w Ein oraz własny znak clivis w Lan.

Nad zaimkiem vos rękopis krakowski notuje dwie neumy: punctum (la) oraz pes (la-do). Glc notuje scandicus quilismaticus (la-si-do), podobnie jak w notacji Lan i Ein. Dodatkowo w Ein kopista umieścił dwie litery: $\boldsymbol{l}$ (ewate) $\boldsymbol{b}$ (ene).

Rzeczownik Dóminus dla każdej z sylab posiada osobne grupy neumatyczne. Sylabie akcentowanej Do w Krk jak i Glc odpowiada clivis (la-sol), w Lan własny 
znak clivis, natomiast Ein stosuje poszerzenie przez epizemę i oznaczą ją dodatkową literą $\boldsymbol{m}$ (ediocriter).

Na sylabie poakcentowanej mi rękopis Krk notuje torculus na dźwiękach sol-la-sol, podobnie jak w rękopisie akwitańskim. Kopista rękopisu z Lan odnotowuje torculus o wartościach poszerzonych w Ein torculus, przy czym jest to forma graficznie wygięta, co wskazywać może na wolniejszy ruch pióra sugerujący kadencję ${ }^{7}$. Ostatnia sylaba nus we wszystkich wersjach posiada neumę jednodźwiękową: Krk i Glc punctum (na stopniu sol), Lan uncinus, Ein tractulus.

Przyimkowi in $\mathrm{w}$ Krk ponownie skryba przypisał likwescencyjne punctum (na stopniu $f a$ ) w Glc punctum $(f a)$, w Lan uncinus, a w Ein tractulus, przy którym dodatkowo znajduje się litera $\boldsymbol{i}$ (usum).

Sylaba akcentowana rzeczownika terram $\mathrm{w}$ kodeksie krakowskim posiada cztery dźwięki zanotowane za pomocą dwóch neum: torculus (dźwięki sol-la-sol) i virga (dźwięk la). Glc notuje tylko torculus (sol-la-sol), z kolei Lan umieszcza torculus likwescencyjny initio debilis z dodatkowymi literami $\boldsymbol{c}$ (eleriter), a(ugete). Rękopis Ein przekazuje torculus z epiphonus (przy pierwszej z nich dodatkowo umieszczając literę $\boldsymbol{s}$ (ursum). Sylaba końcowa rzeczownika terram u wszystkich notatorów otrzymała neumę jednodźwiękową. W Krk i Glc punctum (la), w Lan uncinus, w Ein virga.

Sylabie przedakcentowanej czasownika fluéntem wszyscy notatorzy ponownie przyporządkowali neumę jednodźwiękową: Krk i Glc punctum na stopniu sol, Lan uncinus, Ein tractulus. Sylabie akcentowanej $\boldsymbol{e n}$ kopista Krk przypisał scandicus (sol-la-do) z przystawionym punctum (do), kopiści Lan i Ein scandicus flexus. Tę samą neumę (scandicus flexus) przekazuje manuskrypt Glc, który podaje dokładne wysokości dźwięków (sol-la-do-si). Sylaba końcowa tem w zapisie krakowskim to neuma clivis (si-la), w Glc cephalicus (si-la), a w Lan i Ein (cephalicus diminucyj$n y)$. Dodatkowo ten ostatni przytacza dołącza znak literowy $\boldsymbol{i}$ (usum).

Rzeczownik lac we wszystkich rękopisach posiada neumę jednodźwiękową. W badanym zapisie krakowskim daje się odczytać punctum likwescencyjne (do), w Glc punctum (do), w Lan uncinus, a w Ein virgę.

Nad spójnikiem et skryba krakowski zanotował pes (la-do). W źródle akwitańskim epiphonus (la-do), podobnie zresztą jak w zapisach metzeńskim i sanktgalleńskim.

Rzeczownikowi mel skryba krakowski przypisał cztery dźwięki: punctum (do) oraz climacus (do-la-sol). Pozostałe notacje przekazują melodię sześciodźwiękową, odpowiednio: rękopis akwitański: distropha (do-do), clivis (do-la) oraz clivis (la-

7 E. Cardine, Semiologia gregoriańska, tłum. M. Kaziński, Kraków 2008, s. 42. 
-sol), zapis Lan grupę neumatyczną: distropha, clivis i clivis poszerzona, a notacja z Ein: distropha, clivis i pressus minor z literą $\boldsymbol{t}$ (enere).

Nad sylabą otwierającą rzeczownik alleluia Krk notuje neumę dwudźwiękową pes (la-do), natomiast Glc trzydźwiękowy scandicus quilismaticus (la-si-do). Zapis Lan i Ein notuje scandicus quilismaticus, przy czym ten drugi dodaje litery $\boldsymbol{s}(u r-$ sum) oraz i(usum). Czterodźwiękowa sylaba przedakcentowa le zarówno w Krk, jak i w Glc otrzymała porrectus flexus (la-fa-la-sol). Laon odnotowuje także porrectus flexus, ale $\mathrm{z}$ artykulacją neumatyczną na pierwszym elemencie. Podobnie wygląda zapis neumatyczny w Ein, dodatkowo kopista umieszcza literę $\boldsymbol{i}$ (usum). Sylaba akcentowana $l u \mathrm{w}$ Krk i Glc posiada torculus (sol-la-sol), a w Lan i Ein torculus poszerzony (kadencyjny). Końcowa sylaba ia we wszystkich rękopisach posiada jedną neumę: w Krk i Glc punctum (sol), w Laon uncinus, w Ein tractulus.

Drugi człon badanego introitu otwiera spójnik et, który w kodeksie krakowskim posiada punctum likwescencyjne na dźwięku fa. Kodeks akwitański z Gaillac przekazuje punctum (sol). Lan zapisuje uncinus, a Ein tractulus z literą $\boldsymbol{e}$ (qualiter), która sugeruje, że to dźwięk sol.

Spójnik łączny ut we wszystkich zapisach posiada neumę jednodźwiękową: w Krk punctum likwescencyjne (la), w Glc punctum (sol), w Lan uncinus, $\mathrm{w}$ Ein - tractulus.

Rzeczownikowi lex notator krakowski przypisał scandicus (sol-la-do), natomiast kopiści mezeński, sanktgalleński i akwitański - scandicus flexus. W odróżnieniu od zapisu krakowskiego rękopis Glc przytacza jeden dźwięk więcej (sol-la-do-si), podobnie jak dwa pozostałe źródła.

Sylabie akcentowanej rzeczownika Dómini wszyscy notatorzy przypisują neumę jednodźwiękową. Krk punctum (do), Glc punctum (si), Lan uncinus, Ein virga. Sylabie poakcentowanej mi przypadły następujące neumy: w Krk punctum (do), w Glc punctum (si), a w Lan i Ein tristropha. Ostatnią sylabę ni oznaczono odpowiednio w Krk punctum (do), w Glc tristropha (na dźwięku do), w Lan uncinus, a w Ein virga.

Dla sylaby akcentowanej przysłówka semper Krk notuje torculus (do-re-do), Glc pes subbipunctis o wartościach poszerzonych (do-re-do-la). Również Lan i Ein potwierdzają zapis akwitański. Sylaba końcowa per badanego przysłówka znalazła odwzorowanie odpowiednio w Krk pes (la-si) i clivis (do-la), w Glc punctum (do) i epiphonus (la-si). Lan notuje uncinus i epiphonus, Ein clivis i epiphonus.

Dla czasownika sit wszystkie notacje zapisują jeden znak: Krk punctum likwescencyjne (la), Glc punctum (sol), Lan uncinus, Ein virga.

Przyimkowi in również przypisano jedną neumę: w Krk punctum likwescencyjne $(f a)$, w Glc punctum ( $f a$ ), w Lan uncinus, a w Ein tractulus z literami $\boldsymbol{i}$ (usum) oraz $\boldsymbol{m}$ (ediocriter). 
Rzeczownik ore (na sylabie akcentowanej o) ma w XVI-wiecznym rękopisie pes (sol-la). Notator akwitański zapisuje scandicus (fa-sol-la), metzeński scandicus (punctum, punctum, virga), a sanktgalleński salicus (ze środkowym oriscusem). Sylaba końcowa re we wszystkich przypadkach posiada neumę jednodźwiękową: w Krk punctum (la), w Glc punctum (la), w Lan uncinus, w Ein virga.

Sylaba akcentowana zaimka osobowego vestro ma identyczną neumę we wszystkich źródłach, czyli porrectus flexus. Różnica występuje w wysokości dźwięków - w Krk la-sol-do-la, w Glc LA-SOL-SI-LA. Końcowa sylaba stro również jest przez wszystkich kopistów identycznie oznaczona neumą jednodźwiękową: w Krk punctum (la), w Glc punctum (la), w Lan punctum, w Ein tractulus.

Dla pierwszej sylaby al rzeczownika allelúia kopista krakowski zanotował pes (la-do), Glc notuje cephalicus (do-la), Lan i Ein cephalicus, odpowiednio z lit. $\boldsymbol{a}(u$ gete) i $\boldsymbol{i}$ (usum). Sylaba przedakcentowana le w kodeksie Krk otrzymała punctum (do), w Glc punctum (do), w Lan pes quilisma, w Ein virga. Nad sylabą akcentowaną lu zarówno rękopis krakowski, jak i akwitański notują porrectus flexus (do-si-do-la), a Lan i Ein porrectus flexus likwescencyjny. Ostatnia sylaba - ia - analizowanego rzeczownika ma następujące neumy: w Krk clivis (la-sol), w Glc punctum (la), w Lan uncinus, w Ein tractulus.

W repetowanym rzeczowniku alleluia dla pierwszej sylaby przedkacentowanej al badany zapis odnotowuje pes (sol-la), rękopis Gallac epiphonus (sol-la) a rękopisy z Laon i Einsiedeln - epiphonus. Kolejne sylaby są tożsame dźwiękowo i neumatycznie z pierwszym allelúia zamykającym pierwszy człon analizowanego utworu. Sylaba przedakcentowana le zarówno w Krk, jak i Glc otrzymała porrectus flexus (la-fa-la-sol). Laon odnotowuje podobnie - porrectus flexus - ale z artykulacją neumatyczną na pierwszym elemencie. Podobnie wygląda zapis neumatyczny w Ein, dodatkowo kopista umieszcza literę $\boldsymbol{i}($ usum). Sylaba akcentowana $l u \mathrm{w}$ Krk i Glc ma torculus (sol-la-sol), a w Lan i Ein torculus poszerzony (kadencyjny). Końcowa sylaba $i a$ we wszystkich rękopisach ma jedną neumę: w Krk i Glc punctum (sol), w Laon uncinus, w Ein tractulus.

Melodia kompozycji osadzona jest w ósmym modusie (tetrardus plagalny). Podstawowa analiza melodyczna introitu wykazuje, że stopień finalny sol przypada na słowa kadencyjne (Dóminus, allelúia), a dominanta na stopniu do zostaje wielokrotnie podkreślona (vos, lac, mel, Dómini). Ambitus melodii utworu wynosi oktawę (re-re).

Introit rozpoczyna się od dźwięku re - jest to zarazem najniższy stopień w całym utworze. Kompozytor niejako wyprowadza całość melodii z dolnego rejestru, by już po dwóch sylabach wprowadzić finalis sol i zakończyć na nim czasownik introdúxit. Widać tu wyraźne powiązanie i celowy zabieg kompozytorski - finalis 
symbolizować może ziemię mlekiem i miodem płynącą i już na samym początku zostaje ukazany jako cel ostateczny.

Następnie melodia wznosi się na moment na vos aż do dominanty (dźwięku do), by zaraz opaść i niejako opleść finalis na ważnym rzeczowniku Dómini. W wyrazie tym na sylabie mi został użyty torculus, co można wykorzystać przy kadencjonowaniu (stosując lekkie rozszerzenie w celu podkreślenia znaczenia słowa „Pan”). W kolejnych słowach ponownie wyczuwamy intencję kompozytora. W drodze do ziemi - in terram (przechodząc przez pierwszy stopień skali) - można doświadczyć niejako fenomenu pielgrzymowania poprzez opływającą - fluéntem (melodia płynie tu w kierunku górnym, lekko tylko zaznaczając dominantę) - mlekiem i miodem krainę - lac et mel - które również jako ważne słowa osadzone są na dominancie do. Dodatkowo słowo mel niczym prawdziwy miód spływa w kolejnych dźwiękach jak do „beczułki” toniki sol. Allelúia zamykające pierwszy człon introitu oscyluje w obrębie interwału kwinty, z wyczuwalną kadencją na finalis sylaby akcentowanej (torculus) i końcowej (punctum).

Początek drugiego członu w rękopisie krakowskim w odróżnieniu od pozostałych wersji rozpoczyna się od dźwięku fa, by ponownie wspiąć się na słowach $u t$ lex do dominanty podkreślającej wyraz Dómini. W wyniku dalszej analizy okazuje się jednak, że z punktu widzenia melodii następne słowo - semper - zyskuje na znaczeniu. Kompozytor podnosi w nim melodię do dźwięku re, wyraźnie podkreślając, że zawsze należy mieć prawo Pańskie na ustach. Następnie na zwrocie ore vestro melodia zostaje zawieszona na dźwięku la, niejako w oczekiwaniu na spełnienie obietnicy. Zanim to jednak nastąpi, pierwsze z dwóch końcowych alleluiia zostaje wyniesione na wyżyny dominanty, po to, by w drugim z nich szczęśliwie zostać doprowadzonym do kadencjonowanego (torculus) finalis ziemi obiecanej.

Powyższe analizy przeprowadzone zostały w oparciu o komparację badanej notacji z najstarszymi zachowanymi świadkami utworu. Prawie pięćset lat pozwoliło na zachowanie ogólnej struktury analizowanego introitu, ale zaznaczyło także sporo zmian. Być może w czasach rozwoju wszechwładnej wówczas polifonii trudno było utrzymać „ortodoksyjną” melodię chorałową. Analiza ta w efekcie pozwoliła na wyprowadzenie zasady, którą posługiwał się skryba badanego XVI-wiecznego rękopisu.

Badając zapis introitu Introduxit vos, odnajdziemy wiele cech wspólnych dla zapisu melodycznego w czterech porównywanych rękopisach. Wyraz otwierający, czasownik introduxit, jest tożsamy we wszystkich źródłach i posiada przebieg melodyczny re-re-re-fa-sol-sol-la z zachowaniem właściwych neum: jednodźwiękowej oraz trzydźwiękowej. Kolejnym identycznym melodycznie słowem jest rzeczownik Dóminus, którego kształtowanie melodyczne składa się z następujących neum: clivis la-sol, torculus sol-la-sol i neuma jednodźwiękowa sol. Następnie spój- 
nik in jest tożsamy we wszystkich porównywanych rękopisach, natomiast w wyrazie terram kodeks krakowski jest zgodny co do liczby neum w sylabie ter (sol-la-sol-la) z zapisem sanktgalleńskim - w opozycji do nich pozostają zapis metzeński i spójny z nim akwitański z trzema dźwiękami (sol-la-sol). Sylaba ram jest identyczna w porównywanych rękopisach $(l a)$. W imiesłowie fluéntem pierwsza (sol) i ostatnia $(s i-l a)$ sylaba są tożsame. Zarówno rzeczownik lac (do), jak i spójnik et (la-do) nie wykazują żadnych odstępstw melodycznych. Trzy ostatnie sylaby słowa allelúia są identyczne dla porównywanych notacji (la-fa-la-sol, sol-la-sol, sol).

W drugiej części introitu pierwszym identycznym melodycznie wyrazem jest spójnik ut (dźwięk sol). W wyrazie Dómini możemy uznać, że ostatnia sylaba jest tożsama w rękopisach adiastematycznych, lecz w wypadku rękopisu diastematcznego zgadza się jedynie wysokość dźwięku (odmienna jest neuma). Kolejnymi identycznymi sylabami są spójnik in (dźwięk fa), sylaba re (dźwięk la) w wyrazie ore oraz sylaba tro (la) wyrazu vestro. W rzeczowniku allelúia identyczne są druga sylaba przedakcentowana le (dźwięk do) oraz akcentowana lu (dźwięki do-si-do-la). Ostatni wyraz introitu (allelúia) jest tożsamy we wszystkich manuskryptach (sol-la, la-fa-la-sol, sol-la-sol, la).

Reasumując, w pierwszym członie krakowskiej wersji introitu na dwadzieścia jeden sylab szesnaście z nich jest melodycznie tożsamych dla czterech źródeł, jedna sylaba dla trzech, a cztery są odmienne. Natomiast człon drugi (dwudziestodwusylabowy) posiada tylko jedenaście wspólnych cech melodycznych.

Jak się okazuje, w przypadku notacji krakowskiej jeśli na sylabie tekstu przypada jeden dźwięk, zanotuje ona swoje punctum (co w przypadku notacji adiastematycznych jest uproszczeniem). Neumy dwu- i trzy-, a nawet czterodźwiękowe notuje bezbłędnie: civlis, pes, torculus oraz przypadek porrectus flexus. Jeśli chodzi natomiast o kwestię rytmiczną, zapis krakowski nie rozróżnia neum potoczystych i poszerzonych, utrwala na stronach rękopisu tylko jeden znak.

Odnośnie do odmienności melodycznych w analizowanych notacjach możemy wyróżnić kilka bardzo interesujących przypadków różnic melodycznych. Pierwszy zachodzi wówczas, gdy przy takiej samej neumie na sylabę następuje zmiana wysokości dźwięków. Należy tu wliczyć następujące przypadki: wyraz vos w Krk ma trzy neumy - la-la-do (z pominięciem quilizmy), w pozostałych źródłach występuje quilizma la-si-do. W wyrazie fluéntem sylaba én w Krk ma cztery neumy sol-la-do-do, podczas gdy na przykład źródło Glc podaje zapis sol-la-do-si. Ponadto w wersie drugim spójnik et w Krk ma dźwięk fa, a w Glc - sol. Przy czasowniku sit Krk podaje dźwięk la, podczas gdy Glc - sol.

W świetle przeprowadzonych rozważań można powiedzieć, że w przypadku punctum, jeśli melodia pozostaje na tym samym stopniu (przypadek et), skryba krakowski „ozdabia” to miejsce stopniem niżej, natomiast jeśli melodia ma 
charakter descendentalny (przypadek sit), pomijając niewygodny do wykonania tryton, adaptuje melodię do łatwiejszego trójdźwięku. W przypadku neum wielodźwiękowych przekształcenia melodii dokonują się zgodnie ze stopniem strukturalnym odcinka, na którym znajduje się dany przypadek.

Interesujące są przypadki redukowania neum wielodźwiękowych. Sylabie akcentowanej rzeczownika ore badany zabytek przekazuje pes sol-la, co w porównaniu z notacjami wcześniejszymi okazuje się utratą pierwszego dźwięku scandicusa fa-sol-la. Nad rzeczownikiem lex wcześniejsze notacje przekazują czteroelementowy scandicus flexus, Glc sol-la-do-si, podczas gdy Krk zapisuje sol-la-do, „tracąc” ostatni dźwięk. Podana sytuacja zachodzi nad semper, w którym sylaba akcentowana sem w Glc (do-re-do-la), Lan i Ein zapisana jest za pomocą czterodźwiękowego pes subbipunctis, a w Krk za pomocą torculus (do-re-do). Co ciekawe, choć melodia jest dalej tożsama z innymi rękopisami, kolejny dźwięk (w Krk) przynależy już do nowej sylaby.

Zjawisko uproszczenia melodycznego dotyczy także reperkusji. W analizowanym introicie występuje ono na przykład na sylabie $m i$ w wyrazie Dómini. Tristropha (w notacjach sanktgalleńskiej i metzeńskiej) jest w krakowskim manuskrypcie zredukowana do jednego punctum na dźwięku do. Istnieje dodatkowo niezgodność rękopisów, mianowicie w odróżnieniu od notacji adiastematycznych diastematyczny zapis akwitański przesuwa tristrophę na ostatnią sylabę wspomnianego wyrazu. Słowo Dó-mi-ni w Krk ma zatem odpowiednio trzy punctum na stopniu do, w Lan uncius, tristrophę i uncinus, w Ein virgę, tristrophę i virgę, ale w Glc punctum (si), punctum (si) i tristrophę (do).

Kolejnym przykładem reperkusji wewnątrz grupy neumatycznej jest rzeczownik mel. Kodeks krakowski odnotowuje tylko cztery dźwięki (do-do-la-sol), podczas gdy pozostałe notacje opisują słowo sześcioma neumami - diastematyczne źródło Glc podaje dźwięki do-do-do-la-la-sol.

Interesujące są przypadki upraszczania dźwięków w XVI-wiecznym zabytku. O ile sprawa reperkusji nie jest już w tym czasie znana, o tyle decyzja o eliminacji dźwięków z neumy jest dużej wagi. Okazuje się, że w ówczesnej tradycji wykonawczej dochodziło do utraty pierwszego lub ostatniego dźwięku neumy, który być może był dźwiękiem już mało słyszalnym.

Inny rodzaj ingerencji to rozszerzenie polegające na zmianie melodycznej poprzez dodanie kolejnego dźwięku do neumy. Chodzi o przypadek sylaby kończącej przedostatnie alleluiia. Notator krakowski dodał do oryginalnej neumy jednodźwiękowej dźwięk la (notabene zachowany z linii melodycznej sylaby poprzedzającej), stąd powstała clivis (la-sol).

Godny zauważenia jest przypadek „odwróconej” neumy. W pierwszej sylabie przedostatniego allelúia Krk notuje pes la-do, podczas gdy pozostałe źródła (Glc) 
przekazują epiphonus si-la, notabene neumę pochodzącą od clivis. Jeden przypadek nie daje jednak przesłanek do poprawnego wnioskowania. Być może z diminucyjnego epihponusa na stopniu si jego pierwszy silniejszy rytmicznie element przeszedł na stopień $d o$.

$\mathrm{Na}$ szczególną uwagę w krakowskim rękopisie zasługuje zapis likwescencji ${ }^{8}$.

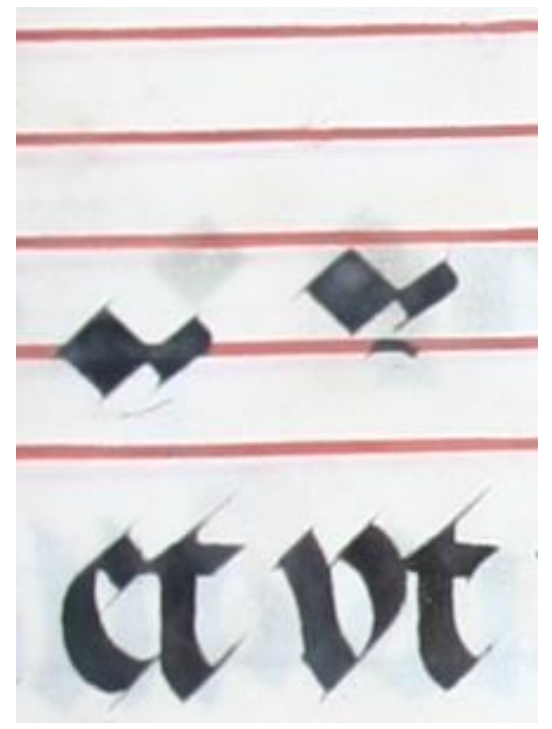

Rycina 1. Zapis likwescencji na stowach et, in. introit Introduxit vos Krk 224/4.

W całym introicie skryba zanotował osiem neum przekazujących to zjawisko. Występuje ono sześć razy na krótkich słowach in, lac, et, ut, sit, in, raz na sylabie otwierającej wyraz introdúxit, wreszcie - co ciekawe - na zamykającej cały introit sylabie ia wyrazu alleluia (w tym ostatnim przypadku zapewne z powodu następującego po introicie wersetu psalmowego). Znak likwescencyjny występuje zawsze przy punctum, ma ukośną formę graficzną, w większości przypadków można doskonale odtworzyć ruch ręki skryby. Interesujące jest to, że w żadnym z wcześniejszych źródeł przy opisywanych miejscach nie występują znaki likwescencyjne.

Jak można się przekonać, notator krakowski dokonuje wielu różnych zmian melodycznych w „swoim” introicie. Niewątpliwie są one znakiem ówczesnej wrażliwości melodyczno-kompozytorskiej, którą można opisać i wytłumaczyć.

8 Jest to zjawisko wokalne wynikające z poprawnej wymowy śpiewanego tekstu. 
Śpiew gregoriański podlegał ewolucji: od utworzenia formy przez jej okres klasyczny aż do czasu dekadencji. Jak jednak się okazuje, epoka śpiewu gregoriańskiego ciągle trwa'! Celem niniejszej pracy było ukazanie przekształceń melodycznych w notacji rękopisu nr 44 Archiwum Krakowskiej Kapituły Katedralnej na przykładzie introitu Introduxit vos. Dzięki przeprowadzonym badaniom analitycznym udało się ustalić miejsca introitu z notacji krakowskiej tożsame melodycznie z jego wersją oryginalną. Jest ich wiele. Bardziej interesujący jest jednak fakt wyłonienia różnic, które z dużą dozą prawdopodobieństwa towarzyszyły notatorowi krakowskiemu, wraz z ich motywem. Zasady, którymi kierował się skryba, są jednoznaczne, co więcej - zachowane są w całym utworze, mówić zatem można o logice notatora. Interesujące było dostrzeżenie własnego punctum likwenscencyjnego, które w zapisie w XVI-wiecznym jest zjawiskiem nieczęstym. Zapis badanego utworu z graduału Krk 44 jest więc odzwierciedleniem wrażliwości ówczesnych czasów. Zanikły w znacznej mierze reperkusje, bardzo charakterystyczne dla stylu śpiewu gregoriańskiego, mobilny stopień si został ściągnięty na mocny do, przebieg interwałowy został uproszczony pod względem intonacyjno-wykonawczym. Zabiegi te wzięły się z ówczesnego stylu muzycznego, które prawdopodobnie miały na celu uwspółcześnić, skorygować „stare” melodie liturgiczne.

Utwór można ocenić, kiedy pozna się jego oryginał. Niech zatem powyższe rozważania staną się impulsem do podejmowania badań nad kolejnymi utworami i kolejnymi zabytkami polskiej kultury muzyczno-liturgiczno-duchowej.

Aneks

1. Tablica porównawcza.

Rycina 2. tablica porównawcza (1)

Rycina 3. tablica porównawcza (2)

2. Fotokopia badanego introitu, rękopis Krk 44.

Rycina 4. Karta 224, introit Intoduxit vos z graduału jana olbrachta ${ }^{10}$

9 M. Białkowski, Semiologia gregoriańska narzędziem rozumienia i interpretowania śpiewu gregoriańskiego. W25. rocznicę śmierci Eugène’a Cardine’a, w: Muzyka sakralna w wymiarze kulturowo-edukacyjnym. Inspiracje i wyzwania, red. J. Bramorski, Gdańsk 2013, s. 35.

10 Autor dziękuje dyrektorowi Archiwum Kapituły Krakowskiej, ks. prof. dr. hab. Jackowi Urbanowi za udostępnienie powyższej karty Graduału Jana Olbrachta w celu wykorzystania jej w niniejszym artykule. 


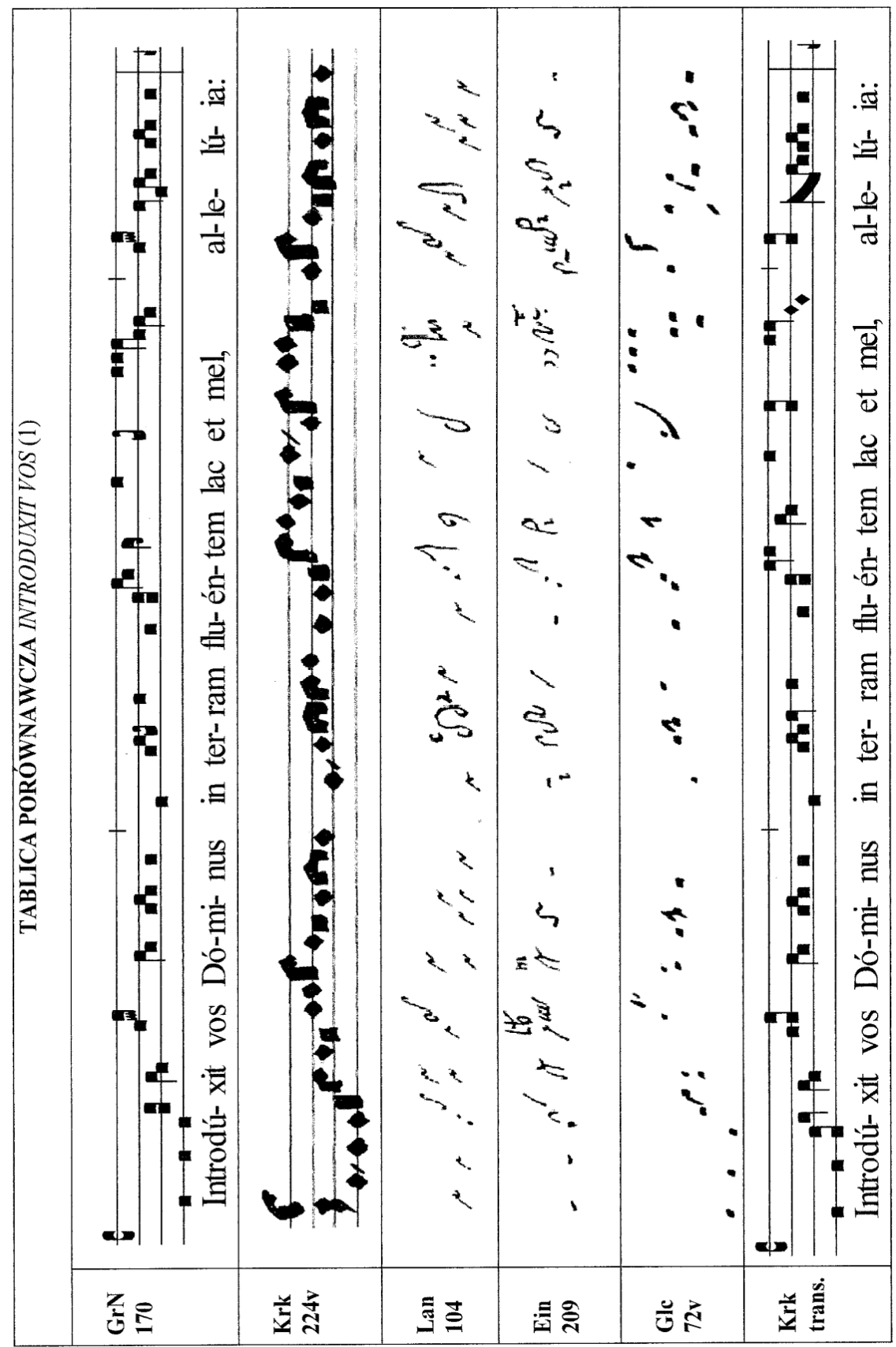

Ryc. 2. 


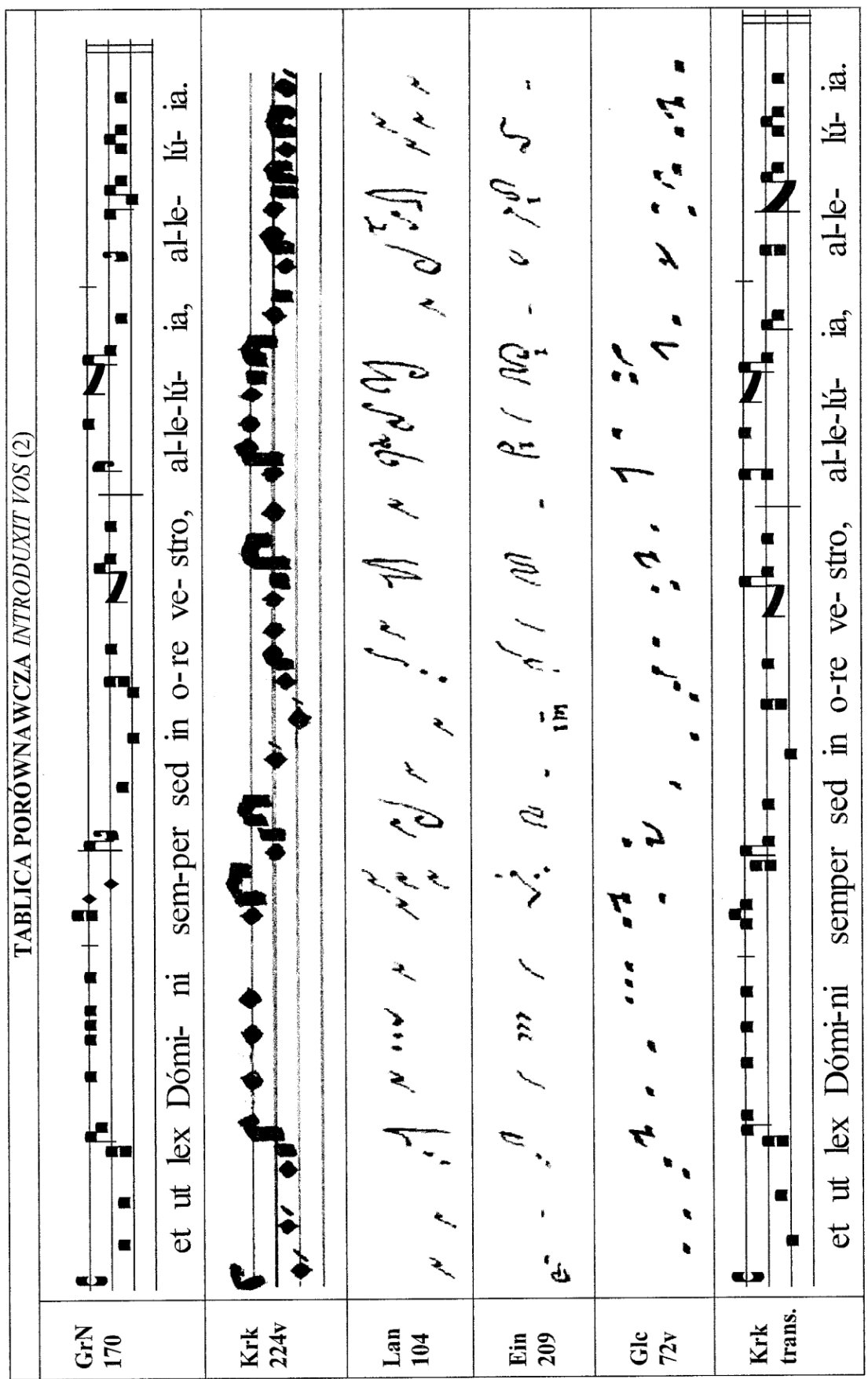

Ryc. 3. 


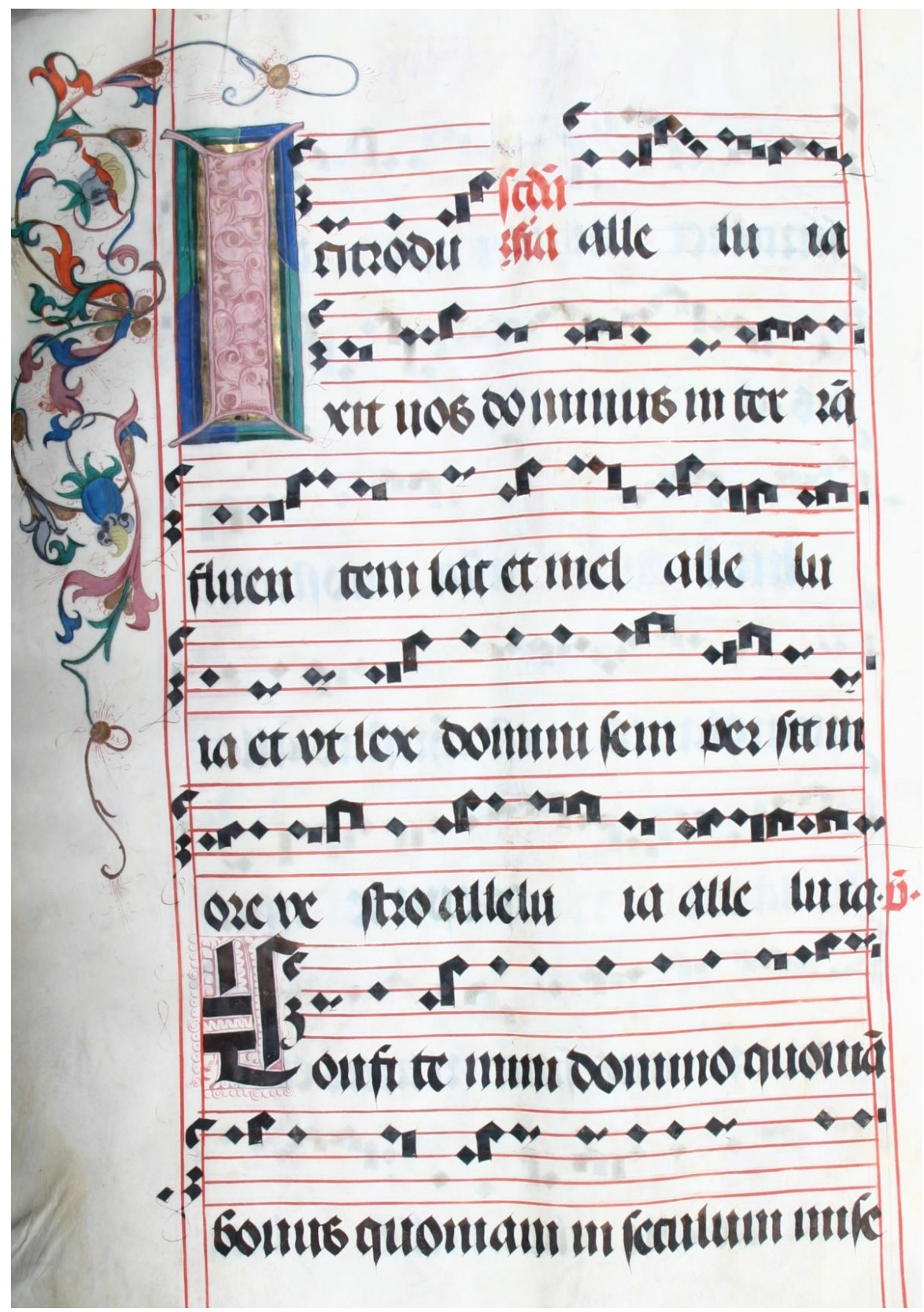




\begin{abstract}
Abstrakt
Przeksztatcenia melodyczne w notacji rękopisu nr 44 Archiwum Krakowskiej Kapituty Katedralnej na przykładzie introitu Introduxit vos
\end{abstract}

W artykule omówiono przekształcenia melodyczne introitu Introduxit vos pochodzącego z krakowskiego graduału Jana Olbrachta (1499-1506). W tym celu dokonano porównania utworu zapisanego w notacji liniowej z zapisami notacji adiastematycznych (sanktgalleńskiej i metzeńskiej) oraz diastematycznej (notacja akwitańska). Analizując krakowską wersję introitu, uwzględniono również tło historyczno-liturgiczne, kontekst tekstowy wraz z jego konstrukcją literacką, warstwę melodyczno-rytmiczną i melodyczno-słowną. W obu przypadkach opisane zostały zarówno tożsamość melodyczna introitu, jak i jej modyfikacje.

W artykule wykorzystano materiały źródłowe (cztery) i inne pozycje bibliograficzne.

Stowa kluczowe: introit, Introduxit vos, przekształcenia melodyczne, graduał, Olbracht, analiza

\title{
Abstract \\ Melodic transformations in the notation of the manuscript No. 44 of the Archives of the Cracow Cathedral Chapter on the example of the introit Introduxit vos
}

The article discusses the melodic transformations of the introit of Introduxit vos originating from the Krakow gradual of Jan Olbracht (1499-1506). For this purpose, a comparison was made between the work recorded in the line notation and the records of adiastematic notations (Sanktgallen and Metzene) and diastematic notation (Aquitaine notation). When analyzing the Krakow version of the introit, were also taken into account the historical-liturgical background, the text context with its literary structure, the melodic-rhythmic and melodic-verbal layers. The melodic identity of the introit and its modifications have been described in both cases.

The article uses source materials (4) and other bibliographic items.

Keywords: introit, Introduxit vos, melodic transformations, gradual, Olbracht, analysis 


\section{Bibliografia}

\section{1. Źródta rękopiśmienne}

Ein - Biblioteka Kapitularna w Einsiedeln, rkps nr 121, 960-970 rok, graduał, w: Paléographie Musicale I/4, codex 121 Einsiedeln. Kommentar zum faximile, Weinheim 1991, notacja sanktgalleńska adiastematyczna.

Glc - Francuska Biblioteka Narodowa w Paryżu, rkps 776, XI wiek, graduał, Codices Gregoriani III, notacja akwitańska.

Krk - Archiwum Krakowskiej Kapituły Katedralnej w Krakowie, rkps nr 44, 1499-1506 rok, graduał, niepublikowany, notacja liniowa.

Lan - Biblioteka Miejska w Laon, rkps nr 239, 930-960 rok, graduał, Paléographie Musicale $\mathrm{I} / 10$, notacja metzeńska adiastematyczna.

\section{2. Źródta drukowane}

GrN - Graduale Novum, editio magis critica iuxta SC 117, t. 1, De Dominicis et Festis, Città del Vaticano 2011.

GrR - Graduale Romanum, Paris-Tornaci-Romae-Neo Eboraci 1961.

Mszat rzymski, Poznań 1963.

Mszat rzymski dla diecezji polskich, wyd. 1, Poznań 1986.

Pismo Święte Starego i Nowego Testamentu, wyd. 3 poprawione, Poznań-Warszawa 1980.

\section{Opracowania}

Białkowski M., Semiologia gregoriańska narzędziem rozumienia i interpretowania śpiewu gregoriańskiego. W 25. rocznicę śmierci Eugène’a Cardine’a, w: Muzyka sakralna w wymiarze kulturowo-edukacyjnym. Inspiracje i wyzwania, red. J. Bramorski, Gdańsk 2013.

Cardine E., Semiologia gregoriańska, tłum. M. Kaziński, Kraków 2008.

Göschl J. B., 100 lat „Graduale Romanum”, Studia Gregoriańskie”, R. II (2009), s. 11-43.

Pikulik J., Śpiew i muzyka w historii liturgii, „Ateneum Kapłańskie” 437 (1980).

Ratzinger J., Nowa pieśn dla Pana. Wiara $w$ Chrystusa a liturgia dzisiaj, tłum. J. Zychowicz, Kraków 1999.

Szczepankiewicz M., Cantate Domino. Szkice o kulturze muzycznej kościoła, Szczecin 2005.

\section{Strony internetowe}

www.de.wikipedia.org/wiki/Codex_Einsidlensis_121 (dostęp: 15.09.2018). 
www.pl.wikipedia.org/wiki/Gradua\%C5\%82_Jana_Olbrachta (dostęp: 15.09.2018). www.fr.wikipedia.org/wiki/Manuscrit_Laon_239 (dostęp: 15.09.2018). 